\title{
Association of single nucleotide polymorphisms in the genes ATM, GSTP1, SOD2, TGFB1, XPD and $X R C C 1$ with risk of severe erythema after breast conserving radiotherapy
}

Annette Raabe ${ }^{1 *}$, Katharina Derda', Sebastian Reuther ${ }^{1}$, Silke Szymczak², Kerstin Borgmann ${ }^{1}$, Ulrike Hoeller ${ }^{3}$, Andreas Ziegler ${ }^{2}$, Cordula Petersen ${ }^{1}$ and Ekkehard Dikomey ${ }^{1}$

\begin{abstract}
Purpose: To examine the association of polymorphisms in ATM (codon 158), GSTP1 (codon 105), SOD2 (codon 16), TGFB1 (position -509), XPD (codon 751), and XRCC1 (codon 399) with the risk of severe erythema after breast conserving radiotherapy.
\end{abstract}

Methods and materials: Retrospective analysis of 83 breast cancer patients treated with breast conserving radiotherapy. A total dose of $50.4 \mathrm{~Gy}$ was administered, applying $1.8 \mathrm{~Gy} /$ fraction within 42 days. Erythema was evaluated according to the Radiation Therapy Oncology Group (RTOG) score. DNA was extracted from blood samples and polymorphisms were determined using either the Polymerase Chain Reaction based Restriction-Fragment-Length-Polymorphism (PCR-RFL) technique or Matrix-Assisted-Laser-Desorption/lonization -Time-Of-Flight-Mass-Spectrometry (MALDI-TOF). Relative excess heterozygosity (REH) was investigated to check compatibility of genotype frequencies with Hardy-Weinberg equilibrium (HWE). In addition, p-values from the standard exact HWE lack of fit test were calculated using 100,000 permutations. HWE analyses were performed using $R$.

Results: Fifty-six percent (46/83) of all patients developed erythema of grade 2 or 3 , with this risk being higher for patients with large breast volume (odds ratio, $\mathrm{OR}=2.55,95 \%$ confidence interval, $\mathrm{Cl}: 1.03-6.31, \mathrm{p}=0.041$ ). No significant association between SNPs and risk of erythema was found when all patients were considered. However, in patients with small breast volume the TGFB1 SNP was associated with erythema $(p=0.028)$, whereas the SNP in XPD showed an association in patients with large breast volume $(p=0.046)$. A risk score based on all risk alleles was neither significant in all patients nor in patients with small or large breast volume. Risk alleles of most SNPs were different compared to a previously identified risk profile for fibrosis.

Conclusions: The genetic risk profile for erythema appears to be different for patients with small and larger breast volume. This risk profile seems to be specific for erythema as compared to a risk profile for fibrosis.

Keywords: Single nucleotide polymorphisms (SNPs), Erythema, Breast cancer, Radiotherapy

\footnotetext{
* Correspondence: araabe@uke.uni-hamburg.de

${ }^{1}$ Department of Radiotherapy and Radiooncology, Laboratory of

Radiobiology \& Experimental Radiooncology, University Cancer Center

Hamburg, University Medical Center Hamburg-Eppendorf, Martinistr

52, D-20246 Hamburg, Germany

Full list of author information is available at the end of the article
} 


\section{Introduction}

The treatment of malignant tumours by radiotherapy (RT) is limited by the need to avoid unacceptable normal tissue toxicity. Despite advances in RT-technique, treatment modalities as well as therapeutic strategies, normal tissue damage is still a limiting factor in radiotherapy. In this context, late complications are especially important because they are generally progressive and appear to be associated with a lifelong risk [1]. In contrast, acute normal tissue toxicity is generally a transient phenomenon, with symptoms settling within months after treatment. However, these effects are not less clinically relevant, especially when accelerated fractionation schedules or adjuvant radiochemotherapy treatment are used [2-4] with new substances often increasing normal tissue toxicity, e.g. Cetuximab.

Both acute and late normal tissue effects are known to vary considerably, ranging from negligible to severe, even between patients treated with identical schedules. It has been suggested that these variations in clinical radiosensitivity mainly result from differences in genetically determined radiosensitivity, as only $30 \%$ of this variation can be attributed to changes in treatment related parameters $[5,6]$. In addition to clinical and genetic parameters for radiation response, a number of patient-related confounding factors exist influencing adverse effects definitely, some of which probably have yet to be identified. Based on this background, pronounced scientific interest is currently being directed towards the use of genetic markers such as single nucleotide polymorphisms (SNPs) as parameters for the individual risk of experiencing radiation-induced normal tissue toxicity. Studies on the impact of SNPs are either performed following the candidate gene approach or employing genome-wide association (GWA) analysis.

So far, numerous studies have been performed, but the results obtained are heterogeneous and often conflicting; for reviews, see $[7,8]$. Even for the C-509 $\mathrm{T}$ polymorphism in the transforming growth factor 1 (TGFB1) gene, which represents one of the most studied SNPs, there are several reports [9-13] showing that this polymorphism promotes chronic inflammatory and fibrotic reactions, but there are also data suggesting a lack of association or even the opposite effect [14-17].

In addition to the identification of those SNPs which are relevant for normal tissue toxicity, their functional consequences concerning the involved molecular pathways and their mechanisms of action are currently of great scientific interest. A respective consortium addressing this topic has recently been established [18].

The discrepancies in the currently available data may be attributed to the fact that with a frequency of about one SNP every 160 to 180 bp [19-21], the vast majority of SNPs are assumed to have no or a small effect on the respective protein or functional pathway. respectively. Therefore individual genetic characteristics must be determined by the combination of several SNPs each one associated with a small effect. This was indicated by previous studies $[7,22]$ which demonstrated a significant association with normal tissue toxicity only if several - each of one only weakly associated SNPs - were combined to a risk score. Such risk scores can easily be created by adding the number of risk alleles per patients and correlating the resulting numerical value with the severity of the normal tissue toxicity.

It is discussed that a risk profile, based on a combination of SNPs in genes which are involved in relevant pathways may vary for the type of normal tissue toxicity scored [7], i.e. different endpoints are characterized by different mosaic-like displays of certain SNPs.

This concept implies that it might be more informative to analyse a certain combination of SNPs in independent studies rather than to change this combination within different studies.

To date, such analyses have only been performed by Andreassen et al. $[10,14,23]$ using certain combinations of SNPs all including SNPs in TGFB1, SOD2, XRCC1, XRCC3, $A P E X$ and $A T M$ genes and studying their association with skin fibrosis in post-mastectomy radiotherapy patients. While the agreement between the first two studies analysing two different cohorts was fairly good [10,14], the third study on a larger cohort of patients [14] failed to confirm the association with radiation induced, indicating that future studies should consider other combination of SNPs [7].

In our studies, we concentrated on six SNPs located in genes (ATM, GSTP1, SOD2, TGFB1, XPD, XRCC1) involved either in the induction or repair of DNA doublestrand breaks and therefore considered to be of relevance for individual radiosensitivity. In a first report, the association of these SNPs with the risk of late tissue effects was analysed for breast cancer patients treated with breast conserving radiotherapy [22]. No significant association with risk was obtained for any individual SNP, as indicated by $p$-values ranging from 0.064 to 0.643 . However, when these SNPs were combined into a risk score, a highly significant association $(p=0.0005)$ was found.

We now investigated in a retrospective study on 83 breast cancer patients the association of these SNPs with the risk of acute tissue toxicity in terms of erythema, with special focus on the relevance of breast size. Erythema grade 2 and more was used as clinical endpoint determined by using the RTOG score. DNA extracted from blood was used to determine the SNP status using either PCR-RFLP or MALDI-TOF. The results imply that fundamental differences exist concerning the risk profile for late and acute tissue toxicity, respectively.

\section{Material and methods Patients}

Blood samples were collected from 83 patients with breast cancer (BC) Stage I/II (postmenopausal; mean age 
of 60.1 at time of treatment (standard deviation, SD: 11.5, range 36-80) who had undergone breast conserving surgery and adjuvant radiotherapy to the breast. This cohort is independent of the one used in the previous study adressing fibrosis [22]. Patients were recruited from the Clinic for Radiotherapy and Radiation Oncology, University Medical Center Hamburg-Eppendorf, and from the Clinic of Radiotherapy, Radiation Oncology and Nuclear Medicine, Vivantes Klinikum Neukölln, Berlin, Germany. Ethical permission as well as informed consent was obtained in advance. Experimental studies were blinded for patient's identity and clinical performance.

Seventy-seven patients were treated with 1.8 Gy per fraction five times per week and six patients received 25 fractions of $2.0 \mathrm{~Gy}$, amounting to a total dose of 50.4 or $50 \mathrm{~Gy}$, respectively. $67 \%$ of patients received a boost of 9 or $10 \mathrm{~Gy}$ administered in five fractions of 1.8 or $2 \mathrm{~Gy}$, respectively. 75 patients received hormonotherapy with tamoxifen. At $50 \mathrm{~Gy}$, prior to boost application, erythema of the breast, excluding folds and scars, was evaluated using the RTOG score. Scoring of acute toxicity was undertaken by a single investigator. Four scores were defined: grade 0: no change compared to baseline, grade 1: faint or dull erythema/ epilation/ dry desquamation/ decreased sweating, grade 2: tender or bright erythema, patchy moist desquamation or moderate edema, grade 3: confluent moist desquamation, pitting edema, grade 4: ulceration, hemorrhage, and necrosis. The study was approved by the local ethics committee.

\section{Genotyping}

DNA was extracted from the whole blood of the patients using a genomic extraction kit (Macherey \& Nagel, Germany). DNA concentrations were determined using a BioPhotometer (Eppendorf, Germany).

GSTP1 (codon 105, rs1695), TGFB1 (position -509, rs1800469), and XRCC1 (codon 399, rs25487) genotypes were determined using PCR-RFLP. The PCR reaction was carried out using $100 \mathrm{ng}$ of genomic DNA in a total reaction volume of $25 \mu \mathrm{l}$ using PuReTaq Ready-To-Go PCR beads (Amersham, United Kingdom). Primer pairs (Table 1) were used at a concentration of 10 pmol. For GSTP1, cycling conditions were $95^{\circ} \mathrm{C}$ for $5 \mathrm{~min}$, followed by 35 cycles of $95^{\circ} \mathrm{C}$ for $30 \mathrm{sec}, 60^{\circ} \mathrm{C}$ for $30 \mathrm{sec}$ and $72^{\circ} \mathrm{C}$ for $30 \mathrm{sec}$, with a final extension of $72^{\circ} \mathrm{C}$ for $5 \mathrm{~min}$. The PCR-product of $176 \mathrm{bp}$ was digested with $\mathrm{BsmAI}$ at $55^{\circ} \mathrm{C}$ for $3 \mathrm{~h}$, forming fragments of $91 \mathrm{bp}$ and $85 \mathrm{bp}$, which were then resolved on $2 \%$ agarose gels. For TGFB1 and $X R C C 1$, cycling conditions were $2 \mathrm{~min}$ at $95^{\circ} \mathrm{C}$, followed by 35 cycles of $95^{\circ} \mathrm{C}$ for $45 \mathrm{sec}, 60^{\circ} \mathrm{C}$ for $45 \mathrm{sec}$ and $72^{\circ} \mathrm{C}$ for $45 \mathrm{sec}$, or $5 \mathrm{~min}$ at $94^{\circ} \mathrm{C}$ followed by 34 cycles of $94^{\circ}$ $\mathrm{C}$ for $30 \mathrm{sec}, 68^{\circ} \mathrm{C}$ for $60 \mathrm{sec}$ and $72^{\circ} \mathrm{C}$ for $60 \mathrm{sec}$, with a final extension of $72^{\circ} \mathrm{C}$ for $5 \mathrm{~min}$, yielding PCR-products of $419 \mathrm{bp}$ or $615 \mathrm{bp}$, respectively. These products were then digested using Bsu36I or MspI to form fragments of
$190 \mathrm{bp}$ and $229 \mathrm{bp}$ for TGFB1, or $376 \mathrm{bp}$ and 239 bp for XRCC1.

Genotyping for the polymorphisms in ATM (codon 1853, rs1501516), SOD2 (codon 16, rs4880) and XPD (codon 751, rs13181) was performed by Bioglobe (Hamburg, Germany) employing the MassARRAY ${ }^{\circledR}$ system (Sequenom, USA), applying the MassEXTEND ${ }^{\circledR}$ [24] (hME) method and MALDI-TOF mass spectrometry for analyte detection. Reactions were performed according to the standard hME protocol recommended by the system supplier. The protocol generates allele-specific analytes in a primer extension reaction applying the primer directly adjacent to the SNP site. After sample conditioning, a MassARRAY ${ }^{\circledR}$ Analyzer Compact was used for data acquisition, followed by automated data analysis with TYPER ${ }^{\circledR}$ RT software version 3.4. Where necessary, the results were reviewed and the operator was revised. Assay design was successfully performed with platformspecific software for the SNP sequence. Failed reactions/ samples were repeated. SNP assays were designed automatically using the MassARRAY platform specific Assay Design software. Additional information was obtained from databases to aid in selecting highly specific primers.

For ATM, a second SNP (rs1801673) has been documented in the direct vicinity (next base pair) of the SNP of interest (rs1801516). Therefore, the assay design was modified to allow for the detection of potentially occurring haplotypes, thus ensuring accurate results. Any risk of potential overlap with the secondary SNP was prevented.

In all cases positive controls were included and ambiguous results verified by means of replication.

\section{Statistical analysis}

Relative excess heterozygosity (REH) [25] was determined to check compatibility of genotype frequencies with Hardy-Weinberg equilibrium (HWE). In addition, p-values from the standard exact HWE lack of fit test were calculated using 100,000 permutations. HWE analyses were performed using $\mathrm{R}$.

Patients were divided into two groups with either no or only moderate erythema (grade 0 and 1) or with severe erythema (grade 2 and 3). Analyses were performed using all patients and subgroups stratified by breast volume. Small breast volume was defined as a volume $<750 \mathrm{~cm}^{3}$, which is the median volume of all patients. Association between breast volume and risk of erythema was tested using the two-sided asymptotic Cochran-Armitage trend test with odds ratio (OR) and asymptotic 95\% confidence intervals (CI) estimated using logistic regression.

Associations between erythema grade and each individual SNP were tested using the two-sided exact Cochran-Armitage trend test. ORs per increase in one allele and exact 95\% CIs were estimated using logistic regression. No adjustment was performed for multiple 
Table 1 SNP characteristics and population

\begin{tabular}{|c|c|c|c|c|c|c|c|c|c|}
\hline Gene & rs no. & SNP $^{a}$ & $\begin{array}{l}\text { Codon/ } \\
\text { position }\end{array}$ & $\begin{array}{l}\text { Change inamino } \\
\text { acid }\end{array}$ & $\begin{array}{l}\text { Function of } \\
\text { gene product }\end{array}$ & Primers & & $\begin{array}{l}\text { Relative excess } \\
\text { heterozygosity } \\
\text { ( } 95 \% \text { confidence interval) }\end{array}$ & $\begin{array}{l}\text { p-value } \\
\text { HWE }^{b}\end{array}$ \\
\hline ATM & rs1801516 & $\mathrm{G} / \mathrm{A}$ & 1853 & Asp $>$ Asn & DNA repair & - & - & $0.802(0.350-1.861)$ & 0.842 \\
\hline GSTP1 & rs1695 & $A / G$ & 105 & $\mathrm{Val}>\mathrm{sol}$ & ROS pathway & $\begin{array}{l}\text { 5'-ACCCCAGGG } \\
\text { CTCTATGGGAA-3' }\end{array}$ & $\begin{array}{l}\text { 5'-TGAGGGCACA } \\
\text { AGAAGCCCCT-3' }\end{array}$ & $1.104(0.670-1.815)$ & 0.924 \\
\hline SOD2 & rs4880 & $\mathrm{C} / \mathrm{T}$ & 16 & Ala $>$ Val & ROS pathway & - & - & $1.798(1.130-2.849)$ & 0.037 \\
\hline TGFB1 & rs1800469 & $\mathrm{C} / \mathrm{T}$ & pos.509 & - & $\begin{array}{l}\text { Pro-fibrotic } \\
\text { cytokine }\end{array}$ & $\begin{array}{l}\text { 5'-CAGACTTCTAGA } \\
\text { GACTGTCAG-3' }\end{array}$ & $\begin{array}{l}\text { 5'-GTCACCAGA } \\
\text { GAAAGAGGAC-3' }\end{array}$ & $0.993(0.640-1.549)$ & 0.987 \\
\hline$X P D$ & rs13181 & $\mathrm{A} / \mathrm{C}$ & 751 & Lys $>$ Gln & DNA repair & - & - & $1.030(0.640-1.656)$ & 0.987 \\
\hline$X R C C 1$ & rs 25487 & $\mathrm{G} / \mathrm{A}$ & 399 & $\operatorname{Arg}>\mathrm{Gln}$ & DNA repair & $\begin{array}{l}\text { 5'-TTGTGCTITC } \\
\text { TCTGTGTCCA-3' }\end{array}$ & $\begin{array}{l}\text { 5'-TCCTCCAGCC } \\
\text { TITCTGATA-3' }\end{array}$ & $0.735(0.460-1.164)$ & 0.424 \\
\hline
\end{tabular}

${ }^{a}$ major allele / minor allele.

${ }^{b} \mathrm{p}$-value of the exact Hardy-Weinberg equilibrium lack of fit test.

testing. The risk score was calculated by counting the number of risk alleles at five loci. Association with grade of erythema was checked using the two-sided exact Cochran-Armitage trend test assuming an additive effect of both alleles. OR and exact $95 \% \mathrm{CI}$ were estimated for an increase in one risk allele. Unless stated otherwise, all tests were performed using StatXact with a nominal type I error level of $5 \%$.

\section{Results}

\section{Acute tissue toxicity}

Figure 1 shows the distribution of skin erythema as determined for 83 breast cancer patients using the RTOG score. One patient exhibited no erythema, 36 patients experienced erythema grade 1, 39 grade 2, and 7 patients developed erythema grade 3, while none of the patients showed grade 4. As reported previously [26], a significant association was observed between the risk of erythema and breast volume $(\mathrm{OR}=2.55,95 \% \mathrm{CI}$ : 1.03-6.31, $p=0.041$ ). This is illustrated in Figure 1 showing that 48 patients with a small breast volume had a $46 \%$ risk to develop erythema of G2 or 3, in contrast to a $69 \%$ risk for 35 patients with large breast volume.

No significant difference was observed in mean age or other individual factors such as smoking habits (data not shown). An analysis using the log-rank test also failed to reveal differences with respect to adjuvant chemo- or hormonal therapy, beam quality or fractionation regime.

\section{Genotype analysis}

DNA extracted from blood samples was used to determine the genotype frequency of the six different polymorphisms (Table 1). In the case of XPD-SNP, genotyping failed in one sample, reducing the total number to 82 patients. The obtained genotype frequencies were comparable to those documented for control populations of European descendent (www.ncbi.nlm.nih.gov). For SOD2, a relative excess heterozygosity of $1.80(1.13-2.85)$ was observed, indicating a deviation from HWE (Table 1). This might result from copy number variations, as documented for this locus [27] (see also http://projects.tcag.ca/variation/). To avoid misinterpretation of the data, this SNP was excluded from further analysis.

Table 2 shows the data obtained from the individual SNP association analysis performed for all patients as well as subgroups of patients with small and large breast volumes. Analysing all patients yielded no statistically significant association between erythema and any polymorphism, with p-values ranging between 0.098 and 1 (Table 2, left part). In contrast, a separate analysis of patients with small breast volume revealed a significant allele-dose dependent association for TGFB1 C-509 T (OR=3.10, 95\% CI: 1.11-10.21, $p=0.028)$. No significant association was found for any of

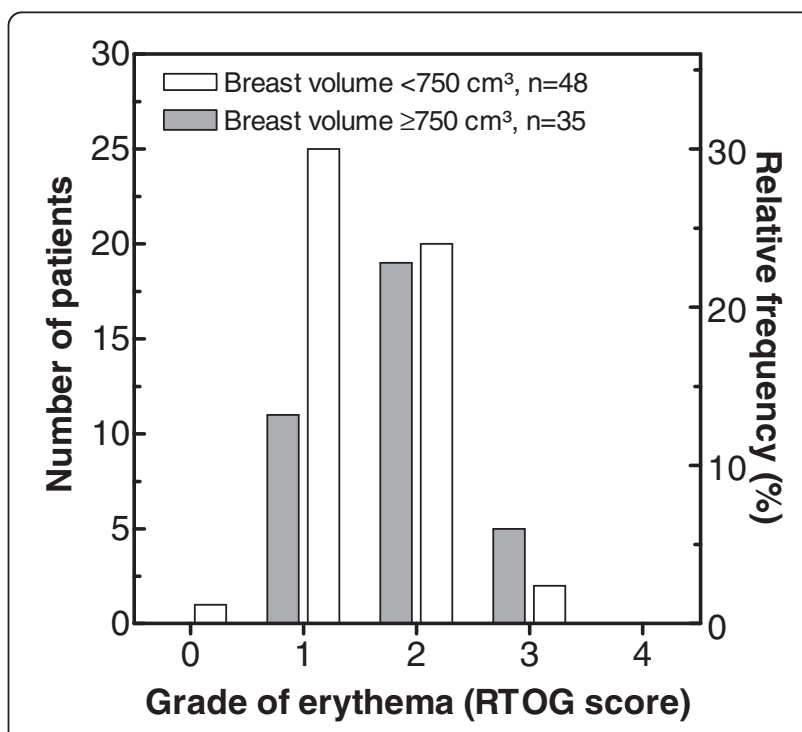

Figure 1 Incidence of breast erythema in 83 patients treated by breast conserving radiotherapy. Data are stratified for a breast volume of $750 \mathrm{~cm}^{3}$. Grade of erythema was determined using the RTOG score. 
Table 2 Association of SNPs with erythema for all patients as well as for the subgroups of patients with breast volume $<$ or $>750 \mathrm{~cm}^{3}$

\begin{tabular}{|c|c|c|c|c|c|c|c|c|c|c|c|c|c|c|c|c|c|c|c|c|c|}
\hline \multirow[b]{2}{*}{$\begin{array}{l}\text { Gene } \\
\text { (codon) }\end{array}$} & \multirow[b]{2}{*}{ Genotype aa } & \multicolumn{7}{|c|}{$\begin{array}{l}\text { all patients } \\
(\mathrm{n}=83)\end{array}$} & \multicolumn{7}{|c|}{$\begin{array}{l}\text { patients with breast volume }<750 \mathrm{~cm}^{3} \\
(\mathrm{n}=48)\end{array}$} & \multicolumn{6}{|c|}{$\begin{array}{l}\text { patients with breast volume } \geq 750 \mathrm{~cm}^{3} \\
(\mathrm{n}=35)\end{array}$} \\
\hline & & n (\%) & $\mathrm{G} 0 / 1^{\mathrm{a}}$ & $G 2 / 3^{a}$ & $O R^{b}$ & $95 \% \mathrm{Cl}^{\mathrm{C}}$ & $P^{d}$ & aa & n (\%) & $\mathrm{G} 0 / 1^{\mathrm{a}}$ & $G 2 / 3^{a}$ & $\mathrm{OR}^{\mathrm{b}}$ & $95 \% \mathrm{Cl}^{\mathrm{C}}$ & $P^{d}$ & aа & n (\%) & $G 0 / 1^{a}$ & $G 2 / 3^{a}$ & $O R^{b}$ & $95 \% \mathrm{Cl}^{\mathrm{C}}$ & $P^{d}$ \\
\hline ATM & GG & $63(76)$ & 28 & 35 & 1 & & & & $36(75)$ & 20 & 16 & 1 & & & & $27(77)$ & 8 & 19 & 1 & $0.19-5.68$ & \\
\hline \multirow[t]{2}{*}{ (1853) } & GA & $18(22)$ & 9 & 9 & 1.18 & $0.45-3.25$ & 0.826 & & $11(23)$ & 6 & 5 & 1.43 & $0.38-5.67$ & 0.573 & & $7(20)$ & 3 & 4 & 0.92 & $0.04-32.21$ & 1.000 \\
\hline & $\mathrm{AA}$ & $2(2)$ & 0 & 2 & 1.38 & $0.20-10.59$ & & & $1(2)$ & 0 & 1 & 2.05 & $0.15-32.15$ & & & $1(3)$ & 0 & 1 & 0.84 & & \\
\hline$\overline{\text { GSTP1 }}$ & $\mathrm{AA}$ & $37(45)$ & 19 & 18 & 1 & & & & $21(44)$ & 12 & 9 & 1 & & & & $16(46)$ & 7 & 9 & 1 & & \\
\hline \multirow[t]{2}{*}{ (105) } & $A G$ & $38(45)$ & 12 & 26 & 1.01 & $0.49-2.09$ & 1.000 & & $21(44)$ & 10 & 11 & 0.98 & $0.39-2.44$ & 1.000 & & $17(48)$ & 2 & 15 & 1.25 & $0.32-5.29$ & 0.772 \\
\hline & GG & $8(10)$ & 6 & 2 & 1.02 & $0.24-4.35$ & & & $6(12)$ & 4 & 2 & 0.96 & $0.15-5.97$ & & & $2(6)$ & 2 & 0 & 1.56 & $0.10-28.03$ & \\
\hline TGFB1 & CC & $29(35)$ & 14 & 15 & 1 & & & & $18(38)$ & 13 & 5 & 1 & & & & $11(31)$ & 1 & 10 & 1 & & \\
\hline \multirow[t]{2}{*}{ (pos-509) } & CT & $40(48)$ & 18 & 22 & 1.26 & $0.65-2.50$ & 0.530 & & $24(50)$ & 12 & 12 & 3.10 & $1.11-10.21$ & 0.028 & & $16(46)$ & 6 & 10 & 0.36 & $0.10-1.14$ & 0.083 \\
\hline & $\pi$ & $14(17)$ & 5 & 9 & 1.59 & $0.42-6.24$ & & & $6(12)$ & 1 & 5 & 9.58 & $1.23-104.30$ & & & $8(23)$ & 4 & 4 & 0.13 & $0.01-1.29$ & \\
\hline$\overline{X P D^{e}}$ & GG & $34(42)$ & 19 & 15 & 1 & & & & $20(43)$ & 12 & 8 & 1 & & & & $14(40)$ & 7 & 7 & 1 & & \\
\hline \multirow[t]{2}{*}{ (751) } & GT & $38(46)$ & 14 & 24 & 1.85 & $0.90-4.00$ & 0.098 & & $20(43)$ & 10 & 10 & 1.42 & $0.59-3.59$ & 0.420 & & $18(51)$ & 4 & 14 & 3.95 & $0.91-22.75$ & 0.046 \\
\hline & $\pi$ & $10(12)$ & 3 & 7 & 3.44 & $0.81-16.01$ & & & $7(14)$ & 3 & 4 & 2.03 & $0.34-12.89$ & & & $3(9)$ & 0 & 3 & 15.62 & $0.84-517.40$ & \\
\hline$\overline{X R C C 1}$ & GG & $36(43)$ & 17 & 19 & 1 & & & & $25(52)$ & 14 & 11 & 1 & & & & $11(31)$ & 3 & 8 & 1 & & \\
\hline \multirow[t]{2}{*}{ (399) } & GA & $33(40)$ & 13 & 20 & 1.02 & $0.54-1.93$ & 1.000 & & $17(35)$ & 9 & 8 & 1.13 & $0.46-2.76$ & 0.840 & & $16(46)$ & 4 & 12 & 0.62 & $0.20-1.84$ & 0.464 \\
\hline & AA & $14(17)$ & 7 & 7 & 1.04 & $0.29-3.73$ & & & $6(12)$ & 3 & 3 & 1.27 & $0.21-7.63$ & & & $8(23)$ & 4 & 4 & 0.39 & $0.04-3.39$ & \\
\hline
\end{tabular}

a Patients with erythema of grade 0 or 1 and grade 2 or 3 .

b Odds ratio per allele.

d $95 \%$ confidence interval.

${ }^{\mathrm{e}}$ Failure to genotype one patient. 
the other four SNPs (Table 2, middle part), but subgroup analysis for patients with larger breast volume yielded a significant association for codon 751 of XPD (OR $=3.95$, 95\% CI: $0.91-22.75, p=0.046)$. Again, no significant association was seen for the other four SNPs.

In addition to the single SNP analysis the association of the combination of all SNPs with erythema was tested. For that the allele associated with an increased risk of erythema was defined as risk allele, which was: A-allele for ATM and XRCC1, T-allele for TGFB1 and XPD and G-allele for GSTP1. However, no significant association with risk of erythema, either for all patients $(\mathrm{OR}=1.20$; 95\% CI: 0.90-1.62; $p=0.209$ ), patients with small breast volume $(\mathrm{OR}=1.36 ; \mathrm{CI}: 0.94-2.04 ; p=0.098)$ or for patients with a large volume $(\mathrm{OR}=0.89$; $\mathrm{CI}$ : $0.52-1.50$; $p=0.712$ ) was detected for this risk profile.

In Figure 2, Odd ratios (OR) as determined for these five SNPs with respect to risk of erythema (taken from Table 2) are compared with the OR previously determined for risk of fibrosis [22]. Obviously, there is a clear difference between these profiles. In contrast to fibrosis no SNP was found to be associated with an enhanced or reduced risk of erythema (Figure 2, open bars) as indicated by Odd ratios not significantly different from 1,0. When this fibrosis related risk score was applied on the erythema data set no significant association was obtained, $(\mathrm{OR}=0.94 ; \mathrm{CI}$ : $0.71-1.25 ; p=0.68)$. These findings emphasizes that the risk of erythema or fibrosis are clearly associated with different SNP profiles.

\section{Discussion}

There is great interest in establishing methods which can be used to predict the individual risk of normal tissue effects after radiotherapy. If these risks were known prior to the onset of therapy, the total dose applied could be reduced in the small proportion of highly sensitive patients and, conversely, radiation dose and possibly the chance to cure could be increased for normal and resistant patients [28,29].

For radiotherapy, the risk of side effects is considered to be determined mostly by treatment-related factors such as dose and dose per fraction, but also to a considerable extent by genetic parameters [5,30]. In this context, SNPs are considered to be the best genetic markers [8].

Following a candidate gene approach, six polymorphisms were selected in genes (ATM, GSTP1, TGFB1, SOD2, XPD, $X R C C 1)$ that are known to be associated with the induction or repair of DNA-damage [31-36]. In our first study on breast cancer patients treated by conserving radiotherapy, these SNPs were compared with the risk of severe radiation-induced fibrosis [22]. For each SNP, only a weak association was found, with p-values ranging between 0.064 and 0.643. However, combining all six SNPs into one risk score yielded a highly significant association $(p=0.0005)$.

In this study, we have now analysed the association of the same SNPs with the risk of acute effects as observed after breast conserving radiotherapy. In order to increase the performance of the study, the inclusion criteria were applied strictly for all treatment parameters; i.e. variation in the total dose was negligible, as 50 or 50.4 Gy were applied using only two fractionation regimes (2.0 or $1.8 \mathrm{~Gy})$. Since total dose is considered to be a crucial factor in studying genetic determinants of radiation response [30], the detriment of a relatively small patient collective was counterbalanced by the extremely homogenously performed treatment.

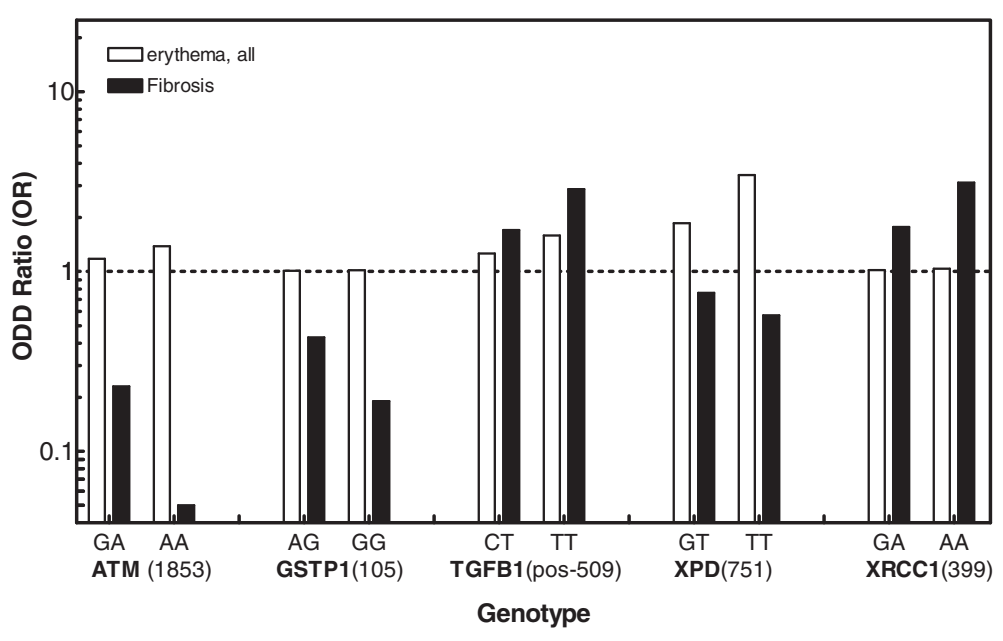

Figure 2 Association of SNPs in ATM, GSTP1, TGFB1, XPD and XRCC1 with risk of either erythema or fibrosis for breast cancer patients treated by conserving radiotherapy. Odd ratios (ORs) obtained are plotted vs. the respective gene variants. Data shown for fibrosis are taken from [22]. 
The association between polymorphisms and acute effects was analyzed using the trend test, which reflects the dosage effect of the number of mutant alleles. Due to deviation from the Hardy-Weinberg-equilibrium, one SNP (SOD2, codon 16) was excluded from the analysis (Table 1). When the analysis was performed with all patients, none of the five SNPs studied was found to show a significant association with erythema (Table 2). This is in line with most other studies in breast cancer patients (for review see [8]) showing no significant association with acute effects for the vast majority of SNPs. An association has only been found for GSTP1 codon 105 [37] - which was, however, not observed in our report (Table 2) - as well as for SNPs in IL12RB2 and in ABCA1 [38] as well as CD44, MAD2L2, PTTG1, RAD9A and Lig3 [39].

Since a previous study [26] proved breast volume to be of importance for the incidence of radiation induced erythema, and other reports also verify breast size as an important confounding factor in the development of radiation-induced erythema [16,40-43] we performed an additional analysis dichomising the patients according to their breast volume. This analysis yields a significant association of TGFB1 C-509 $\mathrm{T}$ for patients with smaller breast volumes and XPD codon 751 for patients with larger breast volume (Table 2). Due to relative small sample sizes we abstained from Bonferoni-correction, following other studies on this issue $\{[8,44,45]$ for Review see $[8,46]$. It cannot be excluded that the observed differences in SNP associations between breast size might be the result of random fluctuations rather than being a reflection of a true difference in the radiobiology of large and small breasts, respectively. Therefore verification studies are needed to test the evolving hypothesis that different pathways and with that different SNPs might be relevant for clinical radiosensitivity according to breast size - and by that possibly to body mass index and metabolic parameters.

For the other four SNPs, no significant association was found (Table 2), even when combined into a risk score. These results indicate that probably due to differences between smaller and larger breasts with respect to micro-milieu and/or metabolism, other parameters and with them other genes are of relevance for the formation of acute effects. As a consequence, more significant associations could potentially have been found in other reports if breast volume had been considered as a relevant confounding factor as done here (Table 2). It has also been shown that the total dose applied must be considered as a relevant confounding factor in a radiogenomic analysis [23,47]. Certainly more of these factors need to be taken into consideration in order to detect the moderate effects caused by a single SNP.

For the five SNPs studied, we also demonstrated that the risk profile obtained for erythema was clearly different from that previously found for fibrosis in breast cancer patients treated by conserving radiotherapy [22]. There are also several reports on breast conserving radiotherapy in which the association between certain SNPs was compared with both acute and late effects. The by far largest study was performed by Chang-Claude and colleagues, analysing the association between polymorphisms in certain DNA repair genes and either acute [48] or late side effects [49]. Although these studies did not always use the same set of polymorphisms, the data obtained confirm that for different clinical endpoints, the risk is determined by different combinations of SNPs. There are numerous reports investigating the impact of mutations in ATM on side effects in breast cancer patients. A clear different influence was seen in one study [50], but not in the others [51-53].

The results obtained in the present study indicate that the endpoints of acute and late tissue toxicity are determined by different molecular and cellular pathways, respectively. Therefore, analysing the association of SNPs with both acute and late effects will help us not only to identify the SNPs which might be used as markers of the respective risks, but also to unravel the underlying biological mechanisms.

\section{Conclusion}

In summary, this study demonstrates for the first time that significant associations between a specific SNP and risk of erythema can be identified if breast cancer patients are grouped by their breast volume. The combination of SNPs using risk alleles according to erythema is substantially different from a risk score previously defined for risk of fibrosis. However, these results need to be replicated in an independent and larger study.

\section{Abbreviations}

SNP: Single Nucleotide Polymorphism; RTOG: Radiation Therapy Oncology Group; PCR-RFLP: Polymerase Chain Reaction based Restriction Fragment Length Polymorphism; MALDI-TOF: Matrix-Assisted-Laser-Desorption/ lonization -Time-Of-Flight-Mass-Spectrometry; OR: Odds Ratio.

\section{Competing interests}

The authors declare that they have no competing interest.

\section{Authors' contributions}

UH collected and analyzed the data, KD and SR performed genotyping procedures. AR reviewed the data and drafted the manuscript. SR, SS and AZ performed statistical procedures. ED and $C P$ revised the manuscript. $K B$ and ED designed the study and revised the final version. All authors read and approved the final manuscript.

\section{Conflict of interest statement}

It is hereby confirmed that all authors disclose all financial and personal relationships with other people or organisations that could inappropriately influence (bias) their work.

\section{Acknowledgements}

The authors thank Ms. Maria Omniczynski and Ms. Alexandra Zielinski for their skillful technical assistance. This project was supported by the Bundesministerium für Umwelt, Naturschutz und Reaktorsicherheit (Grant No 02NUK005B) 


\section{Author details}

${ }^{1}$ Department of Radiotherapy and Radiooncology, Laboratory of Radiobiology \& Experimental Radiooncology, University Cancer Center Hamburg, University Medical Center Hamburg-Eppendorf, Martinistr 52, D-20246 Hamburg, Germany. ${ }^{2}$ Institute of Medical Biometry and Statistics, University at Lübeck, University Hospital Schleswig-Holstein, Campus Lübeck, Lübeck, Germany. ${ }^{3}$ Department of Radiotherapy, Charité University Hospital, Berlin, Germany.

Received: 16 November 2011 Accepted: 18 March 2012

Published: 26 April 2012

\section{References}

1. Jung H, Beck-Bornholdt HP, Svoboda V, Alberti W, Herrmann T: Quantification of late complications after radiation therapy. Radiother Oncol 2001, 61:233-246.

2. Ko C, Citrin D: Radiotherapy for the management of locally advanced squamous cell carcinoma of the head and neck. Oral Dis 2009, 15:121-132.

3. Baumann M, Herrmann T, Koch R, Matthiessen W, Appold S, Wahlers B, Kepka $L$, Marschke $G$, Feltl D, Fietkau $R$, et al: Final results of the randomized phase III CHARTWEL-trial (ARO 97-1) comparing hyperfractionated-accelerated versus conventionally fractionated radiotherapy in non-small cell lung cancer (NSCLC). Radiother Oncol 2011, 100:76-85.

4. Hatton M, Nankivell M, Lyn E, Falk S, Pugh C, Navani N, Stephens R, Parmar $\mathrm{M}$ : Induction chemotherapy and continuous hyperfractionated accelerated radiotherapy (chart) for patients with locally advanced inoperable non-small-cell lung cancer: the MRC INCH randomized trial. Int J Radiat Oncol Biol Phys 2011, 81:712-718.

5. Turesson I, Nyman J, Holmberg E, Oden A: Prognostic factors for acute and late skin reactions in radiotherapy patients. Int J Radiat Oncol Biol Phys 1996, 36:1065-1075.

6. Safwat A, Bentzen SM, Turesson I, Hendry JH: Deterministic rather than stochastic factors explain most of the variation in the expression of skin telangiectasia after radiotherapy. Int J Radiat Oncol Biol Phys 2002, 52:198-204.

7. Alsner J, Andreassen CN, Overgaard J: Genetic markers for prediction of normal tissue toxicity after radiotherapy. Semin Radiat Oncol 2008, 18:126-135.

8. Andreassen CN, Alsner J: Genetic variants and normal tissue toxicity after radiotherapy: a systematic review. Radiother Oncol 2009, 92:299-309.

9. Quarmby S, Fakhoury H, Levine E, Barber J, Wylie J, Hajeer AH, West C, Stewart A, Magee B, Kumar S: Association of transforming growth factor beta-1 single nucleotide polymorphisms with radiation-induced damage to normal tissues in breast cancer patients. Int J Radiat Biol 2003, 79:137-143.

10. Andreassen CN, Alsner J, Overgaard J, Herskind C, Haviland J, Owen R, Homewood J, Bliss J, Yarnold J: TGFB1 polymorphisms are associated with risk of late normal tissue complications in the breast after radiotherapy for early breast cancer. Radiother Oncol 2005, 75:18-21.

11. De Ruyck K, Van Eijkeren M, Claes K, Bacher K, Vral A, De Neve W, Thierens $\mathrm{H}$ : TGFbeta1 polymorphisms and late clinical radiosensitivity in patients treated for gynecologic tumors. Int J Radiat Oncol Biol Phys 2006, 65:1240-1248

12. Giotopoulos G, Symonds RP, Foweraker K, Griffin M, Peat I, Osman A, Plumb $M$ : The late radiotherapy normal tissue injury phenotypes of telangiectasia, fibrosis and atrophy in breast cancer patients have distinct genotype-dependent causes. Br J Cancer 2007, 96:1001-1007.

13. Kim SY, Han SW, Kim GW, Lee JM, Kang YM: TGF-beta1 polymorphism determines the progression of joint damage in rheumatoid arthritis. Scand J Rheumatol 2004, 33:389-394.

14. Andreassen CN, Alsner J, Overgaard M, Sorensen FB, Overgaard J: Risk of radiation-induced subcutaneous fibrosis in relation to single nucleotide polymorphisms in TGFB1, SOD2, XRCC1, XRCC3, APEX and ATM-a study based on DNA from formalin fixed paraffin embedded tissue samples. Int J Radiat Biol 2006, 82:577-586.

15. Damaraju S, Murray D, Dufour J, Carandang D, Myrehaug S, Fallone G, Field C, Greiner R, Hanson J, Cass CE, Parliament M: Association of DNA repair and steroid metabolism gene polymorphisms with clinical late toxicity in patients treated with conformal radiotherapy for prostate cancer. Clin Cancer Res 2006, 12:2545-2554.
16. Barnett GC, Coles CE, Burnet NG, Pharoah PD, Wilkinson J, West CM, Elliott RM, Baynes C, Dunning AM: No association between SNPs regulating TGF-beta1 secretion and late radiotherapy toxicity to the breast: results from the RAPPER study. Radiother Oncol 2010, 97:9-14.

17. Martin S, Sydenham M, Haviland J, A'Hern R, Owen R, Bliss J, Yarnold J: Test of association between variant tgbeta1 alleles and late adverse effects of breast radiotherapy. Radiother Oncol 2010, 97:15-18.

18. West C, Rosenstein BS, Alsner J, Azria D, Barnett G, Begg A, Bentzen S, Burnet N, Chang-Claude J, Chuang E, et al: Establishment of a Radiogenomics Consortium. Int J Radiat Oncol Biol Phys 2010, 76:1295-1296.

19. Chakravarti A: It's raining SNPs, hallelujah? Nat Genet 1998, 19:216-217.

20. Cargill M, Altshuler D, Ireland J, Sklar P, Ardlie K, Patil N, Shaw N, Lane CR, Lim EP, Kalyanaraman N, et al: Characterization of single-nucleotide polymorphisms in coding regions of human genes. Nat Genet 1999, 22:231-238.

21. Halushka MK, Fan JB, Bentley K, Hsie L, Shen N, Weder A, Cooper R, Lipshutz $R$, Chakravarti A: Patterns of single-nucleotide polymorphisms in candidate genes for blood-pressure homeostasis. Nat Genet 1999, 22:239-247.

22. Zschenker O, Raabe A, Boeckelmann IK, Borstelmann S, Szymczak S, Wellek S, Rades D, Hoeller U, Ziegler A, Dikomey E, Borgmann K: Association of single nucleotide polymorphisms in ATM, GSTP1, SOD2, TGFB1, XPD and XRCC1 with clinical and cellular radiosensitivity. Radiother Oncol 2010, 97:26-32.

23. Andreassen CN, Alsner J, Overgaard M, Overgaard J: Prediction of normal tissue radiosensitivity from polymorphisms in candidate genes. Radiother Oncol 2003, 69:127-135.

24. Jurinke $C$, Denissenko MF, Oeth $P$, Ehrich M, van den Boom D, Cantor CR A single nucleotide polymorphism based approach for the identification and characterization of gene expression modulation using MassARRAY. Mutat Res 2005, 573:83-95

25. Ziegler A, König I, Thompson J: Biostatistical aspects of genome-wide association studies. Biom J 2008, 50:8-28.

26. Borgmann K, Hoeller U, Nowack S, Bernhard M, Roper B, Brackrock S, Petersen C, Szymczak S, Ziegler A, Feyer P, et al: Individual radiosensitivity measured with lymphocytes may predict the risk of acute reaction after radiotherapy. Int J Radiat Oncol Biol Phys 2008, 71:256-264.

27. Redon R, Ishikawa S, Fitch KR, Feuk L, Perry GH, Andrews TD, Fiegler H, Shapero MH, Carson AR, Chen W, et al: Global variation in copy number in the human genome. Nature 2006, 444:444-454.

28. Bentzen SM: Potential clinical impact of normal-tissue intrinsic radiosensitivity testing. Radiother Oncol 1997, 43:121-131.

29. Mackay Rl, Hendry JH: The modelled benefits of individualizing radiotherapy patients' dose using cellular radiosensitivity assays with inherent variability. Radiother Oncol 1999, 50:67-75.

30. Bentzen SM, Parliament M, Deasy JO, Dicker A, Curran WJ, Williams JP, Rosenstein BS: Biomarkers and surrogate endpoints for normal-tissue effects of radiation therapy: the importance of dose-volume effects. Int J Radiat Oncol Biol Phys 2010, 76:S145-S150.

31. Hayes JD, McLellan LI: Glutathione and glutathione-dependent enzymes represent a co-ordinately regulated defence against oxidative stress. Free Radic Res 1999, 31:273-300.

32. Lavin MF, Kozlov S: ATM activation and DNA damage response. Cell Cycle 2007, 6:931-942.

33. Liochev SI, Fridovich I: The effects of superoxide dismutase on $\mathrm{H} 2 \mathrm{O} 2$ formation. Free Radic Biol Med 2007, 42:1465-1469.

34. Chen J, Suter B: Xpd, a structural bridge and a functional link. Cell Cycle 2003, 2:503-506

35. Caldecott KW: XRCC1 and DNA strand break repair. DNA Repair (Amst) 2003, 2:955-969.

36. Barcellos-Hoff MH: How tissues respond to damage at the cellular level: orchestration by transforming growth factor-\{beta\} (TGF-\{beta\}). BJR Supp/ 2005, 27:123-127.

37. Ambrosone CB, Tian C, Ahn J, Kropp S, Helmbold I, von Fournier D, Haase W, Sautter-Bihl ML, Wenz F, Chang-Claude J: Genetic predictors of acute toxicities related to radiation therapy following lumpectomy for breast cancer: a case-series study. Breast Cancer Res 2006, 8:R40.

38. Isomura M, Oya N, Tachiiri S, Kaneyasu Y, Nishimura Y, Akimoto T, Hareyama M, Sugita T, Mitsuhashi N, Yamashita T, et al: IL12RB2 and ABCA1 genes are associated with susceptibility to radiation dermatitis. Clin Cancer Res 2008, 14:6683-6689. 
39. Suga T, Ishikawa A, Kohda M, Otsuka Y, Yamada S, Yamamoto N, Shibamoto Y, Ogawa Y, Nomura K, Sho K, et al: Haplotype-based analysis of genes associated with risk of adverse skin reactions after radiotherapy in breast cancer patients. Int J Radiat Oncol Biol Phys 2007, 69:685-693.

40. Back M, Guerrieri M, Wratten C, Steigler A: Impact of radiation therapy on acute toxicity in breast conservation therapy for early breast cancer. Clin Oncol (R Coll Radiol) 2004, 16:12-16.

41. Fernando IN, Ford HT, Powles TJ, Ashley S, Glees JP, Torr M, Grafton D, Harmer CL: Factors affecting acute skin toxicity in patients having breast irradiation after conservative surgery: a prospective study of treatment practice at the Royal Marsden Hospital. Clin Oncol (R Coll Radiol) 1996, 8:226-233.

42. Freedman GM, Anderson PR, Li J, Eisenberg DF, Hanlon AL, Wang L, Nicolaou N: Intensity modulated radiation therapy (IMRT) decreases acute skin toxicity for women receiving radiation for breast cancer. Am J Clin Oncol 2006, 29:66-70.

43. Neal AJ, Torr M, Helyer S, Yarnold JR: Correlation of breast dose heterogeneity with breast size using 3D CT planning and dose-volume histograms. Radiother Oncol 1995, 34:210-218.

44. Burri RJ, Stock RG, Cesaretti JA, Atencio DP, Peters S, Peters CA, Fan G, Stone NN, Ostrer H, Rosenstein BS: Association of single nucleotide polymorphisms in SOD2, XRCC1 and XRCC3 with susceptibility for the development of adverse effects resulting from radiotherapy for prostate cancer. Radiat Res 2008, 170:49-59.

45. Popanda O, Marquardt JU, Chang-Claude J, Schmezer P: Genetic variation in normal tissue toxicity induced by ionizing radiation. Mutat Res 2009, 667:58-69.

46. Becker T, Knapp M: A powerful strategy to account for multiple testing in the context of haplotype analysis. Am J Hum Genet 2004, 75:561-570.

47. Werbrouck J, De Ruyck K, Duprez F, Veldeman L, Claes K, Van Eijkeren M, Boterberg T, Willems P, Vral A, De Neve W, Thierens H: Acute normal tissue reactions in head-and-neck cancer patients treated with IMRT: influence of dose and association with genetic polymorphisms in DNA DSB repair genes. Int J Radiat Oncol Biol Phys 2009, 73:1187-1195.

48. Chang-Claude J, Popanda O, Tan XL, Kropp S, Helmbold I, von Fournier D, Haase W, Sautter-Bihl ML, Wenz F, Schmezer P, Ambrosone CB: Association between polymorphisms in the DNA repair genes, XRCC1, APE1, and XPD and acute side effects of radiotherapy in breast cancer patients. Clin Cancer Res 2005, 11:4802-4809.

49. Chang-Claude J, Ambrosone CB, Lilla C, Kropp S, Helmbold I, von Fournier D, Haase W, Sautter-Bihl ML, Wenz F, Schmezer P, Popanda O: Genetic polymorphisms in DNA repair and damage response genes and late normal tissue complications of radiotherapy for breast cancer. Br J Cancer 2009, 100:1680-1686.

50. lannuzzi CM, Atencio DP, Green S, Stock RG, Rosenstein BS: ATM mutations in female breast cancer patients predict for an increase in radiationinduced late effects. Int I Radiat Oncol Biol Phys 2002, 52:606-613.

51. Appleby JM, Barber JB, Levine E, Varley JM, Taylor AM, Stankovic T, Heighway J, Warren C, Scott D: Absence of mutations in the ATM gene in breast cancer patients with severe responses to radiotherapy. $\mathrm{Br} J$ Cancer 1997, 76:1546-1549

52. Weissberg JB, Huang DD, Swift M: Radiosensitivity of normal tissues in ataxia-telangiectasia heterozygotes. Int J Radiat Oncol Biol Phys 1998, 42:1133-1136

53. Bremer M, Klopper K, Yamini P, Bendix-Waltes R, Dork T, Karstens JH: Clinical radiosensitivity in breast cancer patients carrying pathogenic ATM gene mutations: no observation of increased radiation-induced acute or late effects. Radiother Oncol 2003, 69:155-160.

doi:10.1186/1748-717X-7-65

Cite this article as: Raabe et al: Association of single nucleotide polymorphisms in the genes ATM, GSTP1, SOD2, TGFB1, XPD and XRCC with risk of severe erythema after breast conserving radiotherapy. Radiation Oncology 2012 7:65.

\section{Submit your next manuscript to BioMed Central and take full advantage of:}

- Convenient online submission

- Thorough peer review

- No space constraints or color figure charges

- Immediate publication on acceptance

- Inclusion in PubMed, CAS, Scopus and Google Scholar

- Research which is freely available for redistribution

Submit your manuscript at www.biomedcentral.com/submit
C Biomed Central 